\title{
МОБИЛЬНОСТЬ И ЭНДОГЕННОСТЬ РЕГИОНАЛЬНЫХ ПОЛИТИКО-АДМИНИСТРАТИВНЫХ ЭЛИТ
}

\author{
А.В. Дука \\ (alexander-duka@yandex.ru) \\ Социологический институт РАН - филиал ФНИСЦ РАН, \\ Санкт-Петербург, Россия
}

Цитирование: Дука А.В. Мобильность и эндогенность региональных политико-административных элит // Власть и элиты. 2021. Т. 8, № 1. С. 66-99.

DOI: https://doi.org/10.31119/pe.2021.8.1.3

\begin{abstract}
Аннотация. Статья посвящена проблеме сочиально-пространственной мобильности региональных российских элит (администраторов и депутатов). Показано, ито мобильность является фактором внутренней дифберенцииаци элит. Элиты более мобильны, чем основное население. Различие связано с положением властных персон в иерархии. Об этом свидетельствуют данные как статистики, так и соииологических исследований. Вместе с тем мобильность элитных персон не является константой. Она изменяется во времени. Для характеристики «пространственной устойчивости» используется термин «эндогенность», который шире, чем просто фиксация определенной степени пространственной мобильности индивида или соииальной группь относительно конкретной биографической вехи - рождения, получения (высшего) образования, занятия той или иной должности и т.п. - в ее привязке кадминистративному / географическому / политическому месту. В статье под эндогенностью (укорененностью) понимается устойчивая связь индивида (политика, администратора) с местным сообществом, его интересами и потребностями. «Устойчивая связв» основывается на встроенности в местное сообщество и возникающие при этом социальные отночения различного уровня и характера. Эмпирической основой исследования стали базы биографических данных членов элитного сообщества
\end{abstract}


десяти регионов. В иентре анализа находятся политические и административные элиты на 2020 г. (1124 чел.) Также привлекаются материаль баз данных 2010 г. (651 чел.) и 2015 г. (1510 чел.), а также данные Pосстата. Обнаружено, что существует большой разброс характеристик мобильности и эндогенности властных групп по регионам. Однако показатели мобильности и эндогенности административной и политической элиты хотя и не совпадают, но близки. В большинстве исследуемых регионов происходит усиление укорененности элить, снижение мобильности ее членов. Интегральный показатель эндогенности (эндогенное ядро) в большинстве исследуемых субъектов федерации возрастает. Наблюдается дифференциация показателей эндогенности по возрастным группам. Более молодые политики и администраторы оказываются менее мобильными и более эндогенными. Это может говорить о возникновении устойчивых региональных бассейнов рекрутирования, о стабилизации региональньх властных групп, их закрытии в отношении внешних акторов. Вопреки ожиданиям, наличие "причлого» губернатора («варяга») не оказывает существенного влияния на динамику мобильности/эндогенности региональной административной элить, что может свидетельствовать об относительной автономности региональных бюрократов.

Ключевые слова: элить, депутать, администраторь, регион, маргинальность, чужаки, мобильность, укорененность, эндогенность.

\section{ЭЛИТЫ И МОБИЛЬНОСТь}

Классические теории элит (Г. Моска, В. Парето, Р. Михельс) делали упор на общих характеристиках персон, входящих во властную группу. Это дало основание исследователям как объединить ученых вместе «макиавеллисты» Дж. Бёрнхэма [Burnham 1943; Putnam 1976: 3-4], так и обосновать общие черты, находимые ими у элит — «три С» Дж. Мейселя [Meisel 1962: 4]. В определенной степени такому настрою следовал и Ч.Р. Миллс [Миллс 1959]. Однако уже в современных Миллсу исследованиях появились важные плюралистические мотивы. Было показано, что элиты не столь однородны, как это представлялось ранее, при довольно «простом» дихотомичном анализе «элиты - массы» [Riesman 1977'; Kornhauser 1961; Dahl 2005]. Исследования немецких

${ }^{1}$ Необходимо уточнить, что Дэвид Рисмен избегал термина «элиты». Он писал о «сдвиге в политическом решении от доминирования правящего класса к власти, рассредоточенной среди многих слабо конкурирующих групп 
элит Р. Дарендорфа [Dahrendorf 1969] и британских Э. Гидденса [Giddens 1974] дали новый материал для понимания внутренних структурных характеристик элит как гетерогенных социальных образований. Важным этапом стала типология элит Г.Л. Филда и Дж. Хигли. Авторы показали, что историческое развитие элит в разных социально-политических и экономических условиях порождает различные взаимоотношения внутри элит, которые могут носить достаточно конфликтный характер [Field, Higley 1980]. Помимо собственно элитологических исследований, необходимо сказать об идее мультипликации элит К. Манхейма [Манхейм 1994: 314-316], а также о его наблюдении об «изменении соотношения коренных и мобильных элементов» внутри элиты [Манхейм 1994: 318-320]. Тот социоэкономический процесс, которых исследовал Манхейм, имеет еще одну важную сторону, связанную с функциональной дифференциацией внутри экономически господствующего класса, что привело к появлению различных теорий менеджериализма [Burnham 1941; Putnam 1977; Perkin 1996]. Упомянутые здесь концепции имеют разные основания и различные теоретические обоснования. Между тем существенно, что они описывают с разных сторон один достаточно сложный процесс диверсификации сфер общественной жизни (можно выразится иначе - социальных порядков), социального переструктурирования, в результате которого процессы социальной мобильности, отношения и границы элит и не-элит изменяются, социокультурные образцы социального существования трансформируются. Одновременно с этими «центробежными» тенденциями становятся очевидными и «центростремительные» движения как на региональном, так и на национальном и глобальном уровнях. Оба эти потока современности непосредственно касаются элит различного уровня.

Упоминаемые выше фиксации внутренних различий элитных групп в основном связаны с дифференциацией интересов и ролей. Структурно это, скорее всего, наиболее сильные факторы, влияющие на культурные различия. Вместе с тем существуют и собственно культурные

давления» [Riesman 1977: 163]. Но традиционно он рассматривается как зачинатель идеи, приведшей к концепции плюрализма (или множественности) элит. Разбор и сравнение Корнхаузером книг Миллса и Рисмена создал устойчивую в литературе аналитически критическую персонифицированную дихотомию. 
различия, которые можно выявить при структурно-биографическом анализе властных элит.

Особое внимание заслуживают процессы мобильности элитных персон и возникновение феномена маргинальности и «чужака» в элитном сообществе. Надо сделать важную оговорку. Усиление мобильности в мире отражается прежде всего на элитах, имеющих необходимые ресурсы. Причем процессы глобального и национального уровня имеют много общего. Зигмунт Бауман справедливо отмечал: «[С]корость передвижения, возможности эффективно действовать независимо от расстояния, а также свобода “перемены мест”, предоставленная либо отсутствием локализованных обязательств, либо легкостью их преодоления, являются сегодня главными факторами стратификации как на глобальном, так и на местном уровне» [Бауман 2002: 49]. Однако национальные отличия существуют, и мотивация персон может различаться в зависимости от контекста. Жак Аттали в связи с этим выделял богатых номадов и периферийную элиту [Аттали 1993]. Такого же рода дифференциация есть и внутри государств. В частности, в России, помимо компрадоров и «офшорной аристократии», ориентированной на глобальный уровень оперирования [Королев 2012], можно наблюдать разницу в мобильности представителей разного уровня элитных персон. И если для одних девальвация места [Бауман 2002: 48] стала частью их функционирования, то для других место имеет значение и ощущение территории [Бауман 2002: 51] не потеряно.

С последним связана важная характеристика локальных сообществ: «В ряду многих солидарностей существует особая солидарность по месту общего жительства, дающая основание для особой группировки, не совпадающей с остальными и являющаяся одной из важных социальных координат, определяющих поведение и переживание совместно живущих индивидов». [Сорокин 2008: 526]. То, о чем писал П.А. Сорокин, часто описывается как наличие особой культуры сообщества и идентификации с ней и территорией. Именно в этом духе пишут Н.А. Шматко и Ю.Л. Качанов: «Территориальная идентичность - переживаемые и/или осознаваемые смыслы системы территориальных общностей (“субъективной социально-географической реальности”), формирующие “практическое чувство” и/или сознание территориальной принадлежности индивида» [Шматко, Качанов 1998: 94]. Конечно, можно представить построение региональной идентичности как рациональную стратегию региональных элит по созданию специфического 
товара, продвигаемого на политическом рынке [Гельман 2003]. Тем более что «символический менеджмент», о котором пишет автор, является фактом региональной политики. Кроме того, объективно существующая разной природы особость региона используется властными группами как ресурс в выстраивании своей деятельности. Из ничего очень затруднительно представить нечто. Близкую позицию можно обнаружить в конструктивистском подходе (см., например: [Ачкасов и др. 2020]).

Не оспаривая правомерности упоминаемых подходов, обращу внимание на то, что территориальная солидарность (о чем пишет Сорокин) и идентичность в контексте данных рассуждений важны в связи неоднородностью властных групп по признакам мобильности и эндогенности (укорененности). Оба признака связаны, можно сказать, что они зеркальны. Причем, они описывают как пространственные перемещения, так и социальные. Джон Урри, обобщая работы своих предшественников, указывает на различные аспекты мобильности: мобильность как свойство или способность вещей и людей двигаться; неорганизованная перемещающаяся толпа (mob); социальное движение вверх или вниз по иерархическим позициям, социальное перемещение; полустационарное географическое перемещение, миграция [Урри 2012: 74-76]. В данной статье я буду касаться двух последних аспектов мобильности, которые в значительной степени связаны.

Отличие элитных персон от граждан с более низкой социальной позицией — в большей мобильности [Бауман 2002: 49]. То же относится к потенциальной элите (потенциальному бассейну рекрутирования). Отечественные исследователи отмечают: «...мигрируют в более развитые регионы те граждане, которые имеют хороший доход, высокую квалификацию в профессиональной деятельности. Таким образом, менее развитые регионы покидают наиболее талантливые и профессиональные кадры, что также сказывается на экономике этого региона» [Строев, Кан 2016: 40]. Схожие процессы происходят и на международном уровне (см., например: [Higley, Nieuwenhuysen 2009: 16-17]). Одновременно отмечается важная тенденция в трансграничной миграции: «Мобильным гражданам закрыт доступ не только к политическому лидерству, но и к участию в формировании политической повестки» [Тормошева 2018: 341]. Проблема заключается не только в потенциальной угрозе национальной безопасности, но и в культурных барьерах, а также в наличии доминантных социальных групп [Тормошева 2018: 
340]. Вместе с тем существует элитная миграция и между развитыми регионами. Исследования демонстрируют, что сама миграция является мультимотивационным процессом, где существенным факторами становятся брак и семейное положение. Кроме того, «опыт многих американских мигрантов в Финляндии показывает, что даже те, кто, кажется, принадлежат к глобальной элите мигрантов, могут испытывать проблемы интеграции в принимающем обществе» [Leinonen 2012: 264]. Культура и здесь оказывается важным фактором.

Вместе с тем можно отметить, что в относительно гомогенной социальной среде мигранты из потенциального бассейна рекрутирования имеют определенные шансы. Здесь важно отметить такое их свойство как «пространства предвосхищения» («spaces of anticipation») - oпределенность достижения цели перемещения, обеспечиваемой системой мобильности [Урри 2012: 83]. В данном случае система включает лифты в рамках иерархий и возможность самообеспечения индивидами пространственного перемещения и (полу)стационарного проживания в пунктах назначения. Конечно, «предвосхищать» могут все. Но возможности и степень предвосхищения неравномерно распределены в популяции. И это проблема не психофизиологическая, а социальная, стратификационная. С точки зрения индивидуальной и групповой социально-пространственной мобильности в социально-политическом пространстве можно говорить о «режиме мобильности», характеризующем то, как происходит в данных конкретных условиях мобильность. При высоких финансовых затратах на проезд и аренду/покупку жилья географическое перемещение становится затруднительным («ловушки бедности»). В стране/регионе будет наблюдаться низкая доля миграционной активности. Это касается как персон, стремящихся подняться по иерархической лестнице, так и обычных граждан, занятых поиском работы, лучшего места для проживания. Возникающие постмобильные депривации [Clark, van Ham, Coulter 2014] членами элитного сообщества или преодолеваются, или их не касаются. В случае вертикальной мобильности в дополнение к изложенным обстоятельствам существенное значение имеет структура политических возможностей.

\section{ЭЛИТНЫЕ ЧУЖАКИ И МАРГИНАЛЫ}

Миграция приводит к маргинальности индивидов и групп, участвующих в ней [Парк 2011a; 2011b]. В более общем плане любое соци- 
альное перемещение приводит в той или иной степени к маргинальности. Суть явления - в рассогласованности культурных ориентаций при изменении социальных и пространственных координат. Индивид (группа) попадает в иную культурную среду, и наличествующий опыт и культурные паттерны могут вызывать напряжение и конфликты [Рашковский 1989]. Возможен также конфликт с существующими нормами в силу несогласия с ними [Фарж 1989].

Элиты (региональные в большей степени) часто рассматриваются функционально, как группы выполняющие определенные управленческие функции в (суб)обществе. Культурный аспект функционирования этих групп сводится зачастую к политической или организационной культуре. Между тем любая элита, даже глобальная, локализована. Так, Стивен Белл пишет о национальной укорененности («nationally embedded») международного бизнеса [Bell 1997]. С этим связаны как раз те «переживаемые и/или осознаваемые смыслы», которые характеризуют «здесь и сейчас» существующую социальную группу. В этом отношении длительность проживания и функционирования в конкретном регионе персон, занимающих высокостатусные позиции, способствует не только интериоризации вышеуказанных смыслов, но и их формулированию и корректированию. Важен и противоположный эффект. Укорененность локального политика, выходящего на национальный уровень, влияет на «характеристики, которые могут как проступать, так и не проступать ясно в его карьере национального героя, но которые, несомненно, пришлось бы принять в расчет при необходимости адекватно проанализировать его характер в этих последующих ролях» [Вирт 2005: 72].

Роберт Парк вслед за Георгом Зиммелем, описывая качества мигранта-еврея как чужака и маргинала, упоминает важную характеристику - отсутствие исторического чувства [Парк 2011b: 234], которое в контексте рассуждений автора тесно связано с культурной определенностью пространства. (В современных городах это проявляется, например, в защите историко-культурного архитектурного и ландшафтного наследия.) Возможно и «культурное разночтение», когда социально-географическое пространство может определяться «более прогрессивно», чем оно есть, с точки зрения того, как должно быть в представлениях некоторых элитных групп. Такое рассогласование может приводить к конфликтам, взаимному отчуждению элит и населения [Akhtar 2016; Hasan 2002]. 
Маргинальность членов элитного сообщества может проявляться как минимум вследствие трех обстоятельств. Во-первых, географического перемещения. Во-вторых, вхождения новичка в новую для него социокультурную группу. В-третьих, в силу функции представительства.

Как уже говорилось, пространственная «чуждость» зачастую является стороной культурной инакости. Альфред Шютц в связи с этим отмечает: «Культурный образец группы, с которой чужой хочет сблизиться, не обладает для него авторитетом испытанной системы рецептов, и это происходит так хотя бы потому, что он не участвует в живой исторической традиции, в которой эта система формировалась» [Шютц 2003: 197].

Новичок маргинален, поскольку он несет не только свои прежние (само)идентичности, но и особую культуру поведения, действования. Часто это гипертрофированно воспринимается внешними наблюдателями. Например, идея милитократии: если служил в силовых ведомствах, то ты «силовик» навсегда. Но сколько времени достаточно для интериоризации новой для новичка культуры, связанной с новой социальной ролью? Это зависит в значительной мере от выполняемой им функции (о дискуссии см.: [Гаман-Голутвина 2006: 350-352; Дука 2012]).

Яркий пример вхождение чужака в элиту и его маргинализация представляет собой случай Меган Маркл. Брак с принцем Гарри и титул (и статус) герцогини вроде бы логично ведет к выполнению определенных правил и ритуалов, принятых в королевской семье и в английском аристократическом обществе. Однако американская актриса зачастую их игнорировала. Так, ее первое появление на церемонии выноса знамени перед строем (Trooping the Colour) ознаменовалось нарушением дресс-кода [Hawken 2018]. Вполне естественно, что преданные хранители традиций и этикета следили за ней, пытались контролировать ее жизнь [Aoraha 2021], устраивали заговоры [McCahill 2019]. Закончилось все исключением Гарри и Меган из Королевского дома. Они стали частными лицами. Приход чужака в группу обычно сопровождается стремлением новичка стать партнером группы [Шютц 2003: 198]. В описываемом случае очевидно прослеживались усилия актрисы-герцогини навязать свои представления о должном и возможном доминирующей группе, что, как правило, оказывается невозможным. Аналогичный случай с депутатом Госдумы VIII созыва Евгением Марченко продемонстрировал ограниченность «своеволия» члена элитного сообщества [Депутат Марченко 2021; Единая Россия 2021]. 
Другой аспект маргинальности новичков - они «входят в поле, не имея капитала» [Бурдьё 1994: 252]. Поэтому часто они являются объектами управления, манипулирования со стороны «старших товарищей» и бюрократического аппарата.

Положение российских региональных депутатов (большинство из которых совмещает мандат с основной профессиональной деятельностью) между политикой и не-политикой, между двумя социальными порядками (полями) задает не только их маргинальность, но и возможность эффективно действовать. В каждом социальном пространстве депутат не совсем свой. Как депутат, он представитель населения (или определенных социальных групп). Как социально-экономический профессионал, он политик. Здесь возможна роль объективного посредника [Зиммель 2008]. Собственно, это его функция - представительство интересов. И что важно, он может говорить как от лица «народа», так и от лица «власти» [Бурдьё 1994: 243-246; 2016: 525]. Такая маргинализация членов региональных легислатур создает типаж частичного политика, что способствует размыванию собственно политического пространства.

Не в меньшей степени это относится к бюрократам. Карл Манхейм схватил эту медиативную роль администраторов: «Выступая в качестве посредника между сталкивающимися группами общества или в качестве союзника определенных слоев, бюрократия стремится конституироваться во всяком случае как функциональное общество и обеспечить свою монополию с помощью всех социальных средств, чтобы создать замкнутую организацию, вплоть до наследования должностей» [Манхейм 1994: 291]. Помимо этого, администраторы демонстрируют свою всеобщность, универсальность, представительство интересов «всех». В обоих случаях происходит «присвоение авторитета» групп, от имени которых выступают властные персоны [Бурдьё 1994: 240].

\section{МОБИЛЬНОСТЬ И ЭНДОГЕННОСТЬ РЕГИОНАЛЬНЫХ ЭЛИТ}

Весь набор проблем, очерченных выше, требует большого комплексного исследования. В данной статье я остановлюсь на некоторых. Тем более что наличные данные и исследовательский инструментарий выступают серьезным ограничением. Эмпирической основой анализа стала база данных региональных элит, собранных в секторе социологии 
власти и гражданского общества Социологического института РАН филиала ФНИСЦ РАН. В основном будут использоваться данные трех волн исследований - 2010 г. (6 регионов, 651 персон), 2015 г. (10 регионов, 1510 персон) и 2019-2020 г. (10 регионов, 1124 персон). В выборку входили депутаты региональных легислатур и члены Федерального собрания от регионов (политики, депутаты), а также члены региональных правительств и руководители основных структурных подразделений исполнительной власти регионов (администраторы, бюрократы). В таблице 1 приведены данные по структуре базы данных последней волны.

Таблица 1

Региональная политико-административная элита. 2019-2020 гг.

\begin{tabular}{|c|c|c|c|c|}
\hline \multirow{2}{*}{ Регион } & \multirow{2}{*}{ Данные } & \multicolumn{2}{|c|}{ Элитная группа } & \multirow{2}{*}{ Всего } \\
\hline & & администраторы & политики & \\
\hline \multirow{2}{*}{$\begin{array}{l}\text { Санкт- } \\
\text { Петербург }\end{array}$} & Количество, человек & 67 & 65 & 132 \\
\hline & \% в регионе & 50,8 & 49,2 & 100,0 \\
\hline \multirow{2}{*}{$\begin{array}{l}\text { Ленинградская } \\
\text { область }\end{array}$} & Количество, человек & 50 & 60 & 110 \\
\hline & \% в регионе & 45,5 & 54,5 & 100,0 \\
\hline \multirow{2}{*}{$\begin{array}{l}\text { Ростовская } \\
\text { область }\end{array}$} & Количество, человек & 34 & 76 & 110 \\
\hline & \% в регионе & 30,9 & 69,1 & 100,0 \\
\hline \multirow{2}{*}{$\begin{array}{l}\text { Калининград- } \\
\text { ская область }\end{array}$} & Количество, человек & 43 & 51 & 94 \\
\hline & \% в регионе & 45,7 & 54,3 & 100,0 \\
\hline \multirow{2}{*}{$\begin{array}{l}\text { Костромская } \\
\text { область }\end{array}$} & Количество, человек & 35 & 41 & 76 \\
\hline & \% в регионе & 46,1 & 53,9 & 100,0 \\
\hline \multirow{2}{*}{$\begin{array}{l}\text { Хабаровский } \\
\text { край }\end{array}$} & Количество, человек & 48 & 47 & 95 \\
\hline & \% в регионе & 50,5 & 49,5 & 100,0 \\
\hline \multirow{2}{*}{ Москва } & Количество, человек & 64 & 73 & 137 \\
\hline & \% в регионе & 46,7 & 53,3 & 100,0 \\
\hline \multirow{2}{*}{$\begin{array}{l}\text { Новосибирская } \\
\text { область }\end{array}$} & Количество, человек & 36 & 86 & 122 \\
\hline & \% в регионе & 29,5 & 70,5 & 100,0 \\
\hline \multirow{2}{*}{$\begin{array}{l}\text { Ставропольский } \\
\text { край }\end{array}$} & Количество, человек & 38 & 60 & 98 \\
\hline & \% в регионе & 38,8 & 61,2 & 100,0 \\
\hline \multirow{2}{*}{$\begin{array}{l}\text { Республика } \\
\text { Дагестан }\end{array}$} & Количество, человек & 49 & 101 & 150 \\
\hline & \% в регионе & 32,7 & 67,3 & 100,0 \\
\hline \multirow{2}{*}{ Всего } & Количество, человек & 464 & 660 & 1124 \\
\hline & \% общего итога & 41,3 & 58,7 & 100,0 \\
\hline
\end{tabular}

В исследовании применялся структурно-биографический анализ (см.: [Быстрова и др. 2008: 158-159]). Здесь существенно, что биография 
члена элитного сообщества неотделима от структур и институтов, в которых эта биография содержательно насыщалась. Ч.Р. Миллс по этому поводу писал: «Жизнь индивида нельзя адекватно понять без учета особенностей тех институтов, внутри которых протекает его биография, поскольку именно она фиксирует точки принятия роли, изменения и выхода из нее, а также непосредственный процесс перехода от одной роли к другой» [Миллс 1998: 184].

Выше отмечалось, что мобильность и укорененность естественным образом связаны. Вместе с тем эти характеристики членов региональных элитных сообществ показывают разные стороны их состояния и функционирования. Одновременно они отражают состояние социальной и политической сферы общества. Мобильность элитных персон фиксируется нами как биографические факты социопространственного перемещения индивидов.

Эндогенность (укорененность) рассматривается как устойчивая связь индивида (политика, администратора) с местным сообществом, его интересами и потребностями. Фундаментом "устойчивой связи» является встроенность в региональное сообщество и возникающие при этом социальные отношения различного уровня и характера. В анализе биографий выделяются следующие виды эндогенности (и соответственно категории анализа):

- эндогенность по рождению - совпадение места рождения и места занимаемой должности в настоящее время;

- эндогенность по образованию - совпадение места получения первого высшего образования и места занимаемой должности в настоящее время;

- эндогенность по работе - совпадение места предыдущей должности и места занимаемой должности в настоящее время.

Эндогенное ядро - совпадение места рождения, места получения первого высшего образования, предыдущей должности и занимаемой должности в настоящее время.

Основная задача исследования - выявить тенденции социопространственной мобильности и эндогенности элитных персон. Это позволит делать определенные предположения относительно функционирования региональных элит и сообществ.

Следует сделать несколько предварительных замечаний. Пространственная мобильность весьма неоднородна. Е.А. Островская с коллегами [Островская и др. 2021] на основе идеи Е.С. Вакуленко 
и Н.В. Мкртчян о разных факторах миграции в различных возрастных группах, используя гравитационную модель, выделила три кластера регионов, которые притягивают мигрантов различного типа в зависимости от мотивов миграции - студенты, трудоспособное население, индивиды пенсионного возраста. В данном случае интерес представляет кластер притяжения мигрантов в возрасте высокой экономической активности (из нашего списка туда попали Москва, Санкт-Петербург и Ленинградская область) и кластер образовательного притяжения (в нашей выборке - Москва, Санкт-Петербург, Ростовская, Новосибирская области и Хабаровский край). Последнее существенно с точки зрения пополнения потенциального бассейна рекрутирования региональной элиты. В общем виде дифференциация по миграции регионов выглядит следующим образом (табл. 2).

Таблииа 2

Коэффициент межрегиональной (внутренней) миграции на 10000 населения

\begin{tabular}{|l|c|c|c|c|c|c|c|}
\hline \multicolumn{1}{|c|}{ Регион } & $\mathbf{2 0 1 1}$ & $\mathbf{2 0 1 2}$ & $\mathbf{2 0 1 3}$ & $\mathbf{2 0 1 4}$ & $\mathbf{2 0 1 5}$ & $\mathbf{2 0 1 6}$ & $\mathbf{2 0 1 7}$ \\
\hline Санкт-Петербург & 93,49 & $\mathbf{1 0 0 , 1 8}$ & $\mathbf{1 2 3 , 9 7}$ & 92,01 & 98,26 & 83,29 & 88,36 \\
\hline Ленинградская обл. & 112,26 & 74,58 & 79,36 & 95,82 & 91,77 & 98,22 & 130,13 \\
\hline Ростовская обл. & $-9,41$ & $-0,81$ & $-12,55$ & $-4,39$ & $-16,73$ & $-5,12$ & $-7,07$ \\
\hline Калининградская обл. & 14,45 & 41,46 & 36,51 & 29,28 & 25,33 & 37,40 & 46,80 \\
\hline Костромская обл. & $-38,42$ & $-33,91$ & $-27,88$ & $-16,19$ & $-25,36$ & $-17,37$ & $-29,04$ \\
\hline Хабаровский край & $-0,47$ & $-35,47$ & $-19,68$ & $-43,76$ & $-51,19$ & $-33,39$ & $-31,21$ \\
\hline Москва & 38,16 & 76,33 & 78,34 & 47,63 & 81,40 & 17,93 & 79,33 \\
\hline Новосибирская обл. & 32,72 & 44,28 & 41,05 & 21,28 & 13,45 & 9,44 & 4,25 \\
\hline Ставропольский край & $-11,14$ & $-12,92$ & $-16,70$ & $-9,83$ & $-20,18$ & $-13,55$ & $-21,71$ \\
\hline Республика Дагестан & $-75,27$ & $-82,64$ & $-74,12$ & $-49,31$ & $-47,25$ & $-36,73$ & $-40,97$ \\
\hline
\end{tabular}

Источник: Коэффициент межрегиональной (внутренней) миграции на 10000 населения // Сайт Федеральной службы государственной статистики. URL: https://showdata.gks.ru/report/274822/ (дата обращения: 10.11.2021).

Как уже отмечалось, пространственная мобильность членов элитного сообщества выше, чем у простых граждан. Но разные регионы демонстрируют существенное различие в соотношении мобильности и иммобильности (рис. 1). 


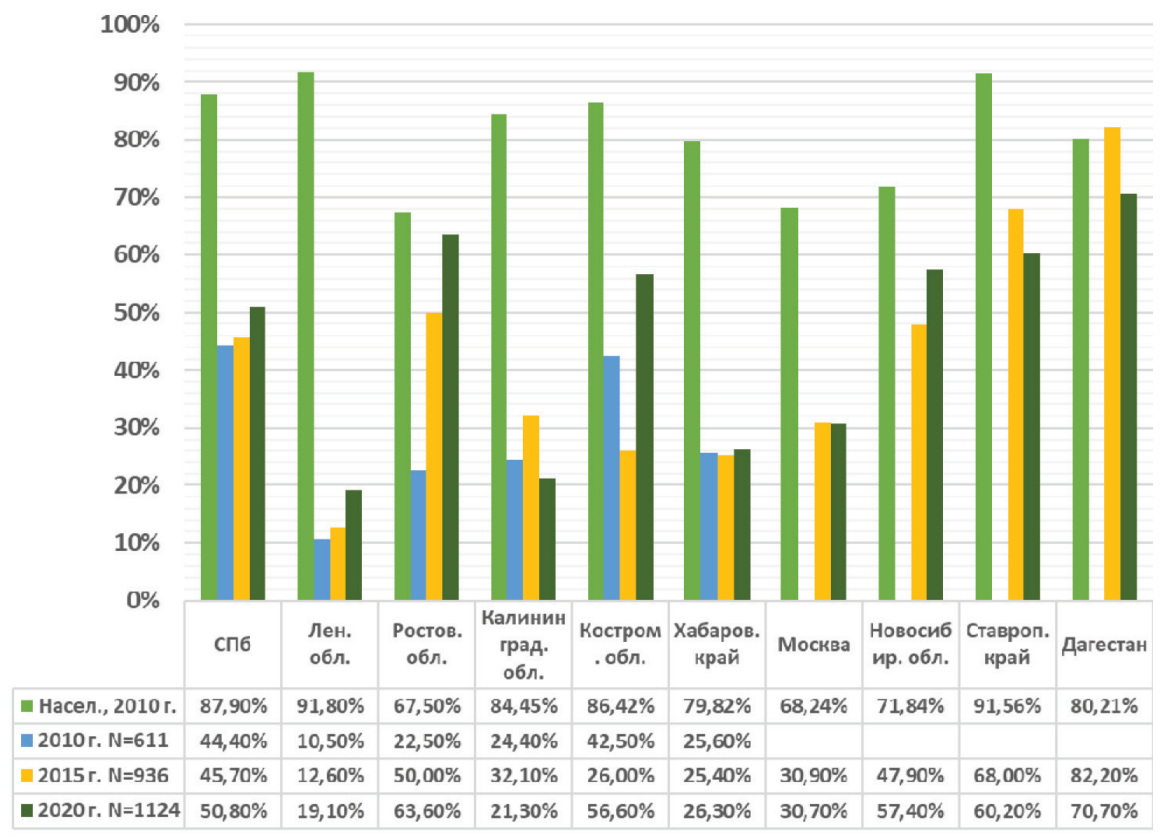

Рис. 1. Совпадение места рождения членов элитного сообщества и места занимаемой ими должности и места рождения населения региона и места его проживания в 2010 г.

Данные по населению: Население по месту рождения и месту проживания на территории Российской Федерации // Итоги Всероссийской переписи населения 2010 года. URL: https://www.gks.ru/free_doc/new_site/perepis2010/ croc/Documents/vol8/pub-08.03.pdf (дата обращения: 04.01.2020).

В большинстве регионов элита демонстрирует большую активность по сравнению с остальным населением. Как видно, в четырех регионах мобильный элемент доминирует во властных структурах. При этом в половине субъектов федерации наблюдается тенденция к увеличению доли лиц, являющихся их уроженцами.

Можно предположить, что среди администраторов доля родившихся в других регионах будет превышать аналогичную группу среди депутатов. Тем более что практика назначения с последующим избранием губернаторов-«варягов» стала в стране почти повсеместной. А в рассматриваемых регионах только в трех «свои» губернаторы - Ленинградская область, Санкт-Петербург и Костромская область. В двух последних случаях губернаторы до своего назначения трудились в иных 


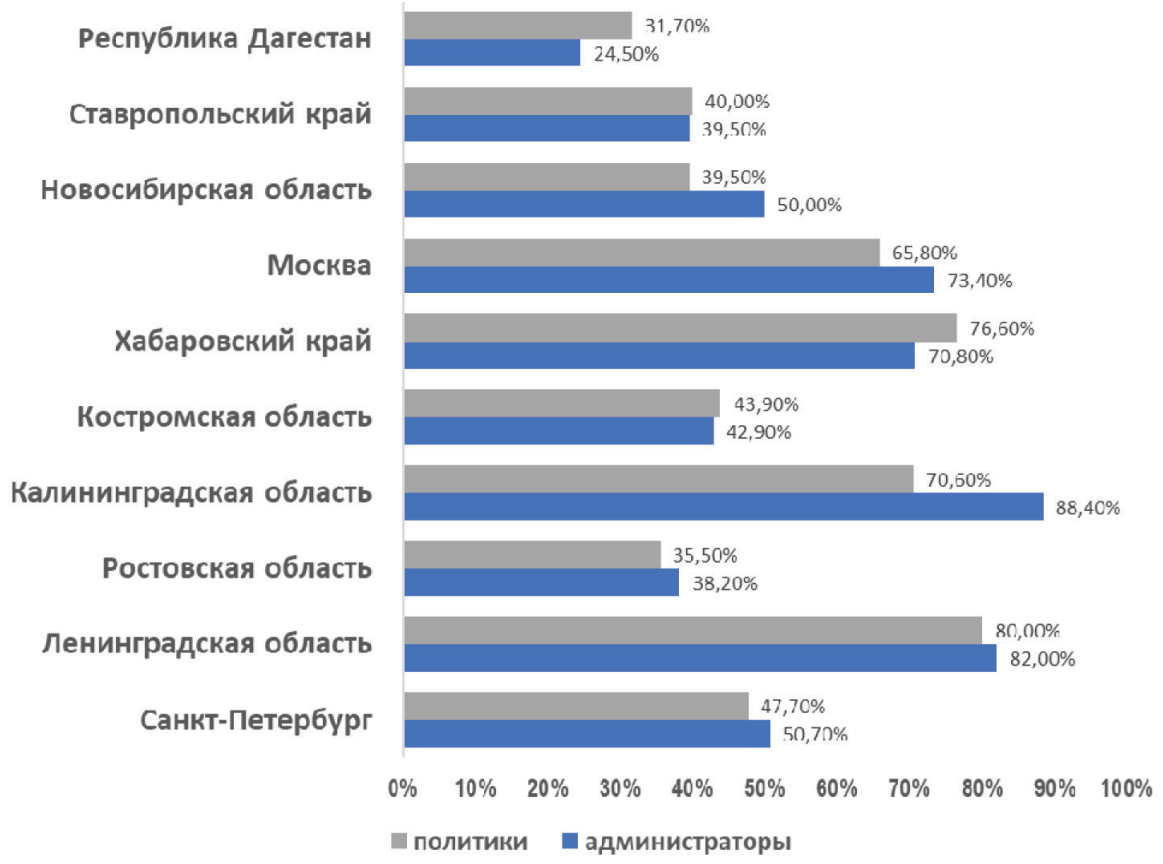

Рис. 2. Доля членов элитного сообщества, родившихся в других регионах (2020 г.; $\mathrm{N}=1124$ )

регионах. Но административная элита оказывается несильно связанной с этими переменами. Хотя, нужно отметить, что ключевые фигуры вполне могут сопровождать своего патрона и на новом месте. Регионы очень различаются (рис. 2).

Доминирование мигрантов среди элитных персон в Москве вполне объяснимо. Этот город является всероссийским «пылесосом», засасывающим и потребляющим разнообразные ресурсы, включая людские. Хабаровский край при отрицательном сальдо межрегиональной миграции - важный центр Дальнего Востока. А до декабря 2018 г. город Хабаровск был столицей федерального округа. В отличие от российского востока, запад более привлекателен для мигрантов. Калининградская область прибывает трудовыми ресурсами и потенциальной элитой. Поэтому высокие показатели мобильности среди властных персон закономерны. Хотя есть одно важное обстоятельство. В Калининградской области 84,45 \% жителей там родились. Диспропорция между населением и начальством большая. Это может подтверждать тезис о большей 
мобильности и энергичности «личности элитного типа». Низкий мобильный потенциал Республики Дагестан объясняется сохранением традиционных структур и социальных отношений среди значительной части жителей региона. Укорененность здесь выступает значительным ресурсом для людей, претендующих на властные позиции.

Сравнение с данными в таблице 2 показывает, что связь статистически незначима. Во всяком случае показатели межрегиональной миграции впрямую не влияют на миграцию элитных персон в данных регионах. То же относится и к валовому региональному продукту на душу населения.

Данные по эндогенности по месту получения первого высшего образования (табл. 3) демонстрируют большую связь с местом руководящей работы и расположением вуза, где учился член элитного сообщества. Этот показатель важен, поскольку именно здесь создается образовательный ресурс индивида и закладывается одновременно его «взрослое» отношение к месту своей активности.

Таблица 3

Совпадение места получения первого высшего образования и места занимаемой должности региональных элит, \% (2010, $\mathrm{N}=611 ; 2015, \mathrm{~N}=936 ; 2020, \mathrm{~N}=1124)$

\begin{tabular}{|c|c|c|c|c|c|c|c|c|c|c|}
\hline Год & 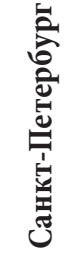 & 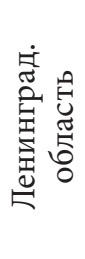 & 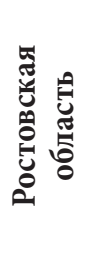 & 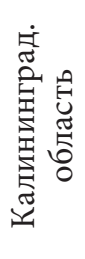 & 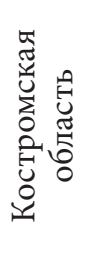 & 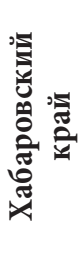 & 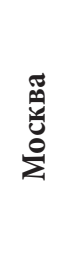 & 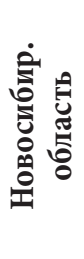 & 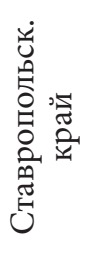 & 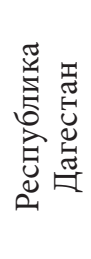 \\
\hline 2010 & 71,9 & ,0 & 55,8 & 22,5 & 27,9 & 48,8 & - & - & - & - \\
\hline 2015 & 77,2 & 60,2 & 76,0 & 91,0 & 74,0 & 84,1 & 91,9 & 90,8 & 94,0 & 33,7 \\
\hline 2020 & 84,1 & 4,5 & 76,4 & 33,0 & 56,6 & 50,5 & 58,4 & 64,8 & 55,1 & 70,0 \\
\hline
\end{tabular}

В таблице выделены центры образовательного притяжения. Однако если в случае Санкт-Петербурга и Ростовской области рост выпускников «своих» вузов среди региональной элиты находится в рамках ожидаемого, то с тремя другими центрами ситуация отличается. Скорее всего, снижение показателя эндогенности по образованию можно объяснить большей открытостью элитного рынка. Особенно это касается Москвы. 
Как видим, картина весьма пестрая. Особо выделяется Ленинградская область. Фактическим центром в этой части Северо-Запада России является Санкт-Петербург. В области до 1990-х годов не было своих высших учебных заведений. Местом высшего образования для областных жителей был прежде всего Ленинград. Затем стали открываться многочисленные филиалы столичных, петербургских и иных институтов и университетов. Через некоторое время начался процесс упорядочивания российского вузовского образования. Число филиалов резко сократилось. Кстати, такие же временные «скачки» в образовательной эндогенности можно наблюдать и в других регионах, где, скорее всего, положение с вузами и филиалами было схожее.

Вторым выделяющимся случаем выступает Калининградская область. Значительная доля в элите пришлого элемента, приехавшего в регион уже после вуза, создает потенциал культурного конфликта. Конечно, сама территория достаточно поздно вошла в состав государства. По большому счету все здесь приезжие. Но для чувства места и исторического чувства (о котором писал Р. Парк) важна длительная сопричастность, которая формируется в детстве и юности и задает социальное, культурное и политическое осмысление данного места. Примечательным примером может служить присвоение объекту культурного наследия (здания школы) в городе Правдинске имени нацистской поэтессы Агнес Мигель [Власти Калининграда 2016; Популяризация Мигель 2016]. Также можно к этому разряду отнести повторяющуюся «кёнигсбергизацию» Калининградской области.

Если рассмотреть дифференциацию между политиками и бюрократами, то можно заметить примечательный факт. Во всех регионах, за исключением Костромской области, депутаты в большей степени образовательно укоренены (табл. 4). Но обнаруженная статистическая связь слабая (Тay-b $=0,136 ; \mathrm{p} \leq 0,000)$.

Вместе с тем можно предположить, что административный набор отличается от отбора через избирательную кампанию. Депутат непосредственно связан с местным населением. Он представляет региональный и локальный интерес, а бюрократ должен эффективно действовать, подчиняясь начальству и правилам.

Различий в пропорциях мужчин и женщин среди получивших первое высшее образование в регионе занятия элитной позиции и обучавшихся в другом субъекте федерации нет. Но есть различие в месте рождения. Различие между большим городом и другими населенными 
Таблица 4

Совпадение места получения первого высшего образования и занимаемой должности региональной элиты. 2020 г., \%

\begin{tabular}{|l|c|c|c|}
\hline & $\begin{array}{c}\text { Администраторы. } \\
\mathbf{N = 6 6 0}\end{array}$ & $\begin{array}{c}\text { Депутаты. } \\
\mathbf{N = 4 6 4}\end{array}$ & $\begin{array}{c}\text { Всего. } \\
\mathbf{N = 1 1 2 4}\end{array}$ \\
\hline Санкт-Петербург & 80,6 & 87,7 & 84,1 \\
\hline Ленинградская область & 4,0 & 5,0 & 4,5 \\
\hline Ростовская область & 67,6 & 80,3 & 76,4 \\
\hline Калининградская область & 25,6 & 39,2 & 33,0 \\
\hline Костромская область & 65,7 & 48,8 & 56,6 \\
\hline Хабаровский край & 39,6 & 61,7 & 50,5 \\
\hline Москва & 51,6 & 64,4 & 58,4 \\
\hline Новосибирская область & 52,8 & 69,8 & 64,8 \\
\hline Ставропольский край & 44,7 & 61,7 & 55,1 \\
\hline Республика Дагестан & 53,1 & 78,2 & 70,0 \\
\hline
\end{tabular}

пунктами в социально-психологическом и социологическом плане весьма красочно описал Георг Зиммель [Зиммель 2002]. Большой город иначе социализирует индивида. Городские жители более мобильны. Тому есть много подтверждений - научных и бытовых. Но в данном случае ситуация иная (корреляция есть, но слабая). Среди уроженцев столичных городов (Москва и Санкт-Петербург) обнаруживается 72,8 \% лиц, получивших образование и нашедших свое элитное призвание именно в этих регионах. В прочих городах эндогенной элиты таких персон 58,2 \%, а среди уроженцев сел - 55,7 \%. Объясняется это довольно тривиально: дифференциация по высшим учебным заведениям повторяет дифференциацию по признаку эндогенности по месту получения первого высшего образования.

Вполне резонно предположить, что большинство высших региональных чиновников и депутатов перед своей нынешней элитной позицией работали в том же регионе (табл. 5). Следует отметить, что вероятность этого увеличивается, если член элиты обучался в этом же регионе.

Кроме Дагестана, во всех регионах видно увеличение эндогенности по работе членов регионального элитного сообщества. Причем в некоторых регионах этот показатель существенно вырос, что может свидетельствовать о достаточно устойчивом развитии политико-админи- 
стративной сферы субъектов федерации и о высокой степени институционализации региональной элиты. Вместе с тем важно детально посмотреть на этот процесс по регионам. Рисунок 3 демонстрирует секторальную дифференциацию по этому показателю.

Таблица 5

Совпадение места предшествующей работы и места элитной позиции, \% $(2010, \mathrm{~N}=483 ; 2015, \mathrm{~N}=936 ; 2020, \mathrm{~N}=1124)$

\begin{tabular}{|c|c|c|c|c|c|c|c|c|c|c|}
\hline & 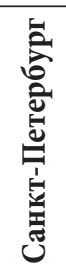 & 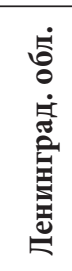 & 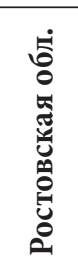 & : & 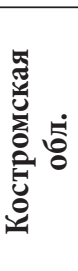 & 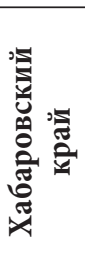 & 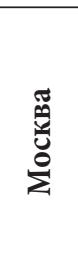 & 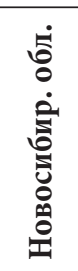 & 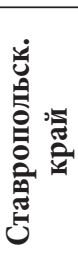 & 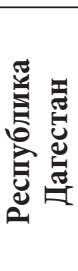 \\
\hline 2010 г. & 57,9 & 8,6 & 67,5 & 10,0 & - & - & - & - & - & - \\
\hline 2015 г. & 81,5 & 1,9 & 51,9 & 37,2 & 33,8 & 55,6 & 57,7 & 72,3 & 64,0 & 78,2 \\
\hline 2020 г. & 87,9 & 76,4 & 95,5 & 86,2 & 93,4 & 83,2 & 97,1 & 94,3 & 96,9 & 61,3 \\
\hline
\end{tabular}

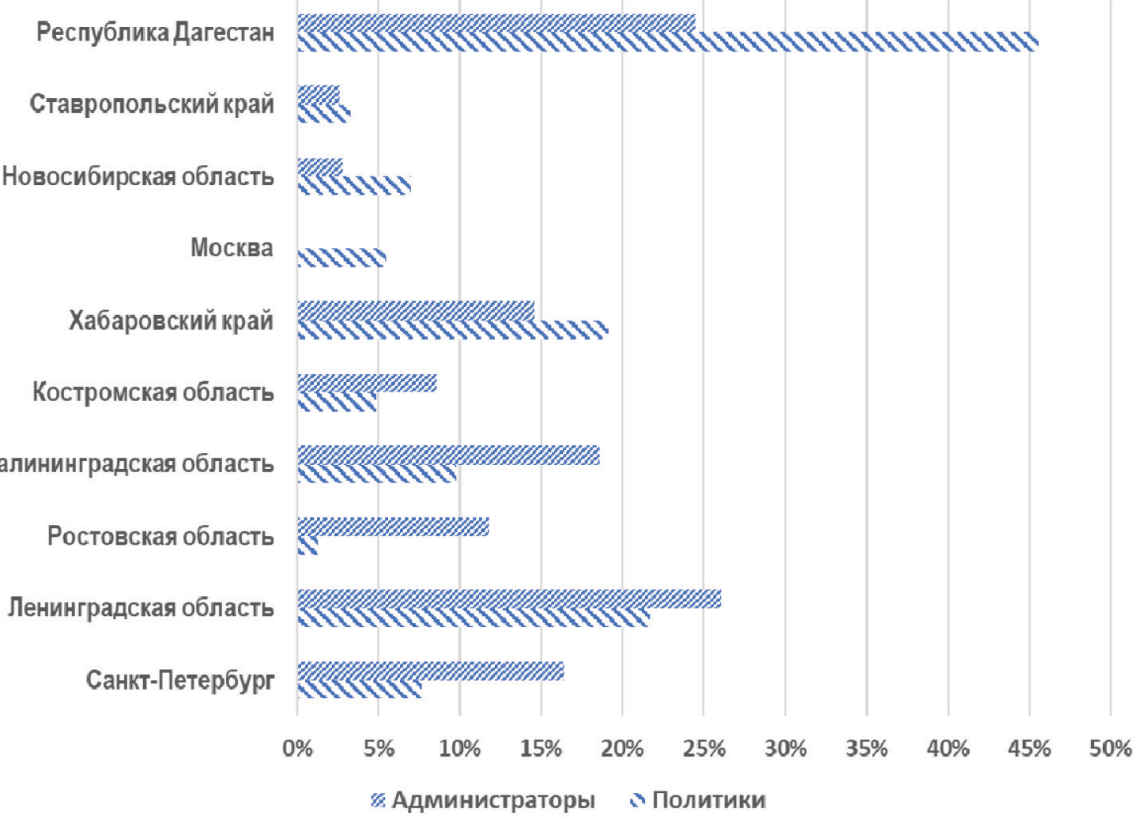

Рис. 3. Доля членов региональной элиты, ранее не работавших в регионе занятия нынешней позиции (2020г.; $\mathrm{N}=1124)$ 
Мобильность элиты в разных регионах и администраторов и депутатов различается. Наиболее подвижной оказалась бюрократическая элита Дагестана. Сложные процессы в республике, связанные с борьбой федерального Центра с коррупцией и непотизмом, назначением главой республики представителя Москвы, повлекли за собой существенные кадровые перемены, приход чиновников, работавших в других регионах. «Вторжение» центральных властей в дела региона и в формирование региональных властных структур наблюдается также в Хабаровском крае.

В большинстве регионов администраторы выслуживаются до элитной должности у себя дома. О Ленинградской области я уже выше писал. Фактически единый социополитикоэкономический комплекс Санкт-Петербург - Ленинградская область задает особенности мобильности и укорененности областной элиты. Очень устойчивая по рассматриваемому показателю политическая элита Москвы (но там всего 35 депутатов на многомиллионный город), Новосибирской, Костромской областей и Ставропольского края.

Мобильная и эндогенная группы элиты различаются по предэлитной карьере. В первой группе относительно больше, чем во второй, хозяйственников и бизнесменов (44 против 40 \%) и силовиков (12 против $4 \%)$. Во второй больше лиц, занимавшихся политико-административной деятельностью (48 против $31 \%$ ).

Интегральный показатель - ядро эндогенной элить - наиболее жестко разделяет «совсем своих» для региона членов элитного сообщества и пришлых, «варягов». В массиве 2019-2020 гг. из 1124 персон к ядру принадлежит 365 человек, 32,5 \%. Это значительная доля. В 2015 г. таких лиц было 21,6 \%. Можно предположить, что если бы не «коррекционные» воздействия Центра, то доля эндогенной элиты в настоящее время была бы больше.

Скорее всего, среди маломобильных групп региональной элиты развито стремление не подвергаться риску нисходящей социальной мобильности, связанной с переездом в чужой регион, где часто семейные социальные связи отсутствуют, а элитные позиции редки (об этом см., например: [Toscano 2008: 13]). Укорененность увеличивает шансы остаться в элитном кругу и стабилизирует положение свое и семьи. Но это только если нет желания двигаться дальше и выше.

При сравнении со всем населением регионов (рис. 4) видно различие не только региональных элит, но и самих регионов по миграционной активности. 


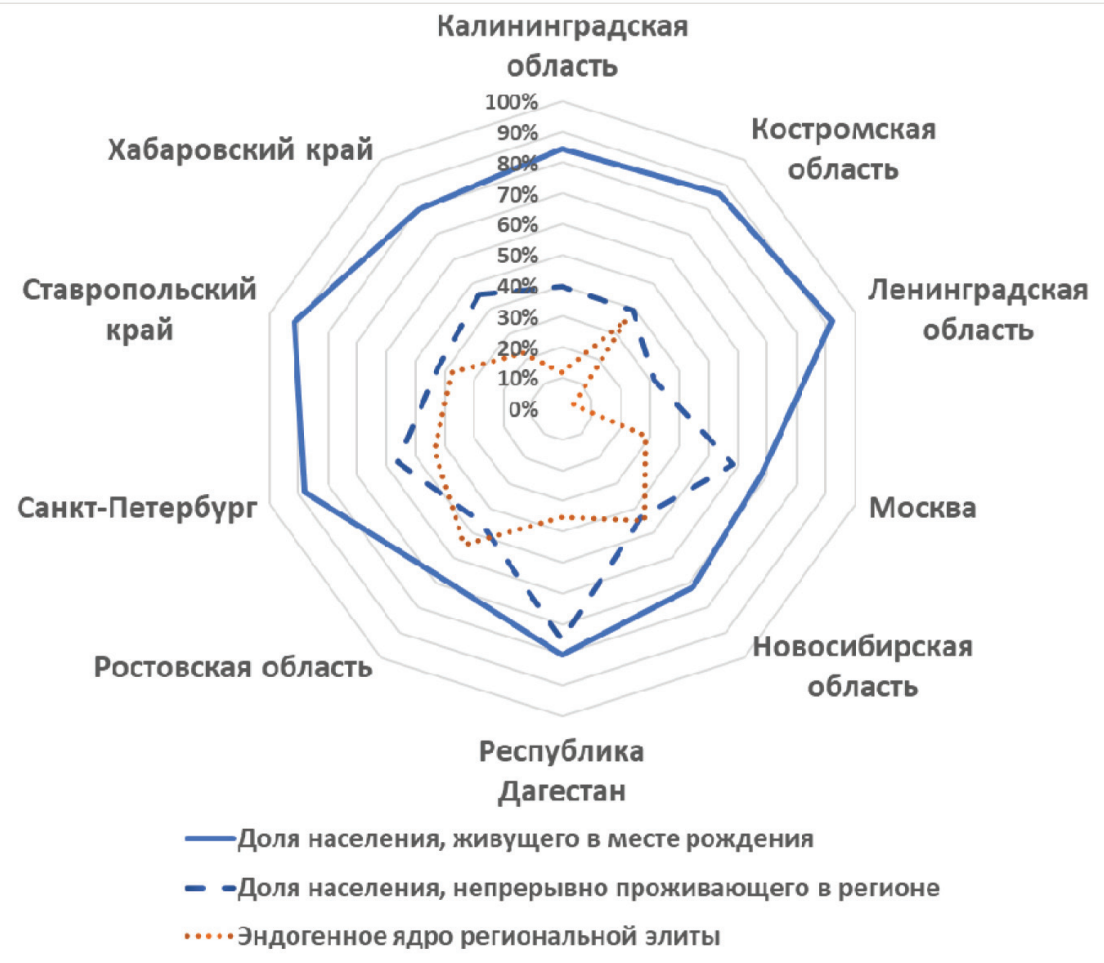

Рис. 4. Эндогеннность населения и региональных элит

Источники: По элитам - База биографических данных (2019-2020 гг.). По населению - Население по месту рождения и месту проживания на территории Российской Федерации // Итоги Всероссийской переписи населения 2010 года. URL: https://www.gks.ru/free_doc/new_site/perepis2010/croc/Documents/vol8/ pub-08.03.pdf (дата обращения: 04.01.2020); Население частных домохозяйств по продолжительности проживания, полу и возрастным группам по субъектам Российской Федерации // Итоги Всероссийской переписи населения 2010 года. URL: https://www.gks.ru/free_doc/new_site/perepis2010/croc/Documents/vol8/ pub-08.01.pdf (дата обращения: 04.01.2020).

Дистанция между мобильностью населения и региональных элит не везде одинаковая. В части регионов дифференциация очень большая. А в Ростовской, Костромской, Новосибирской областях и Ставропольском крае по сравнению с постоянно проживающим населением это не так. Имеющиеся данные не позволяют уверенно интерпретировать полученные результаты. Из общих соображений понятно, что в Даге- 
стане сохраняющиеся традиционные структуры (особенно в сельской местности) способствуют малой мобильности населения. Элита же это прежде всего, как нам говорит теория, энергичная и мобильная часть населения. Но в Ленинградской, Костромской и Калининградской областях, Санкт-Петербурге и Ставропольском крае проживающих в месте рождения в процентном отношении больше. Все это пока вопросы к последующему исследованию.

Разница между администраторами и депутатами есть. Она колеблется между 1,3 \% в Ленинградской области и 10,4 \% в Санкт-Петербурге. Вместе с тем бросается в глаза сходство образцов эндогенности (рис. 5).

При численном различии между секторами элиты, по существу, одинаково отличаются от населения этих же регионов. Это может говорить о региональном культурном паттерне (даже имея в виду влияние центральной федеральной власти на формирование региональных структур).

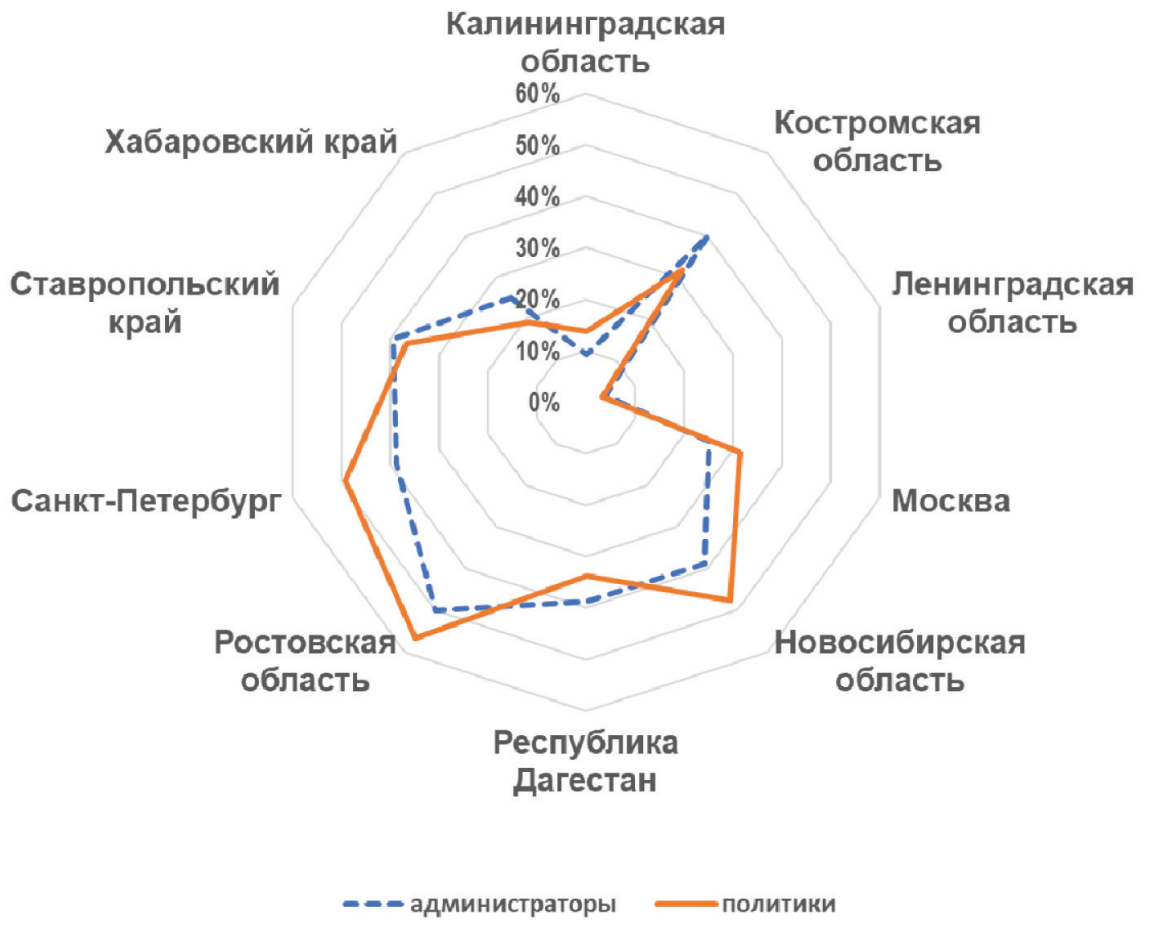

Рис. 5. Эндогеннное ядро административных и политических региональных элит. 2019-2020 гг. 
Возрастание эндогенности проявляется в дифференциации возрастных групп. Принадлежность к эндогенному ядру в большей степени характерна для молодых возрастных групп. И это расходится со стандартным профилем миграции. Как пишут отечественные исследователи, «самой низкой интенсивностью миграции в России характеризуются пожилые люди и дети школьных возрастов» [Карачурина, Мкртчян 2016: 51]. Но в региональной элите наблюдается иное. Так, в возрастной группе 56-85 лет обнаружено 29,7 \% таких персон, в группе 41-55 лет их уже 35,9 \%, а в молодой группе 22-40 лет - уже 43,5 \%. Причем такая тенденция характерна почти для всех регионов. Исключение составляют Республика Дагестан (здесь наибольшую укорененность демонстрируют старшие возрастные группы), Калининградская и Новосибирская области с большей пропорцией эндогенных персон в средней возрастной группе. Уменьшение эндогенности с возрастом связано, возможно, с большей вероятностью пространственной миграции с возрастом. Молодые еще просто не успели поменять место приложения своих сил, обзавестись необходимой известностью и связями. Но в контексте предыдущих данных все же более вероятно, что региональные элиты постепенно замыкаются в своем социогеографическом пространстве.

Место рождения члена элиты оказывается существенным для его мобильности и эндогенности (рис. 6). В диаграмме не отражена заграница как место рождения, а также Москва и Санкт-Петербург.

По месту рождения депутаты - более сельские. Учитывая, что в большинстве регионов существуют сельские поселения и соответственно избирательные округа, это естественно. Но при этом группа относительного большинства у укорененных депутатов сосредоточена по рождению в областных и республиканских центрах (29,8 \%), а у соответствующей группы администраторов - в селе $(26,6$ \%). Разница, конечно, небольшая. Если же иметь в виду, что только 22,3 \% укорененных администраторов родилось в центрах регионов, то структурная разница станет больше видна.

Вместе с тем среди мобильных элитных персон оказывается достаточно большое количество сельских уроженцев, что свидетельствует о немаленькой пробивной способности сельских мигрантов, а также об относительной проницаемости социальных границ.

Среди депутатов, принадлежащих к эндогенному ядру, распределение параллельных занятий не отличается от пропорций между мобильными и укорененными политиками. 


\section{Место рождения региональной элиты}

\section{Д / не эндогенное ядро}

Д / эндогенное ядро

А / эндогенное ядро

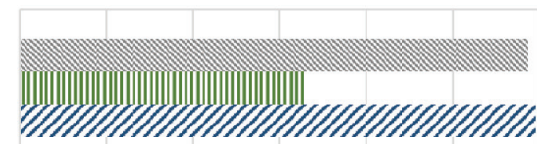

А / не эндогенное ядро
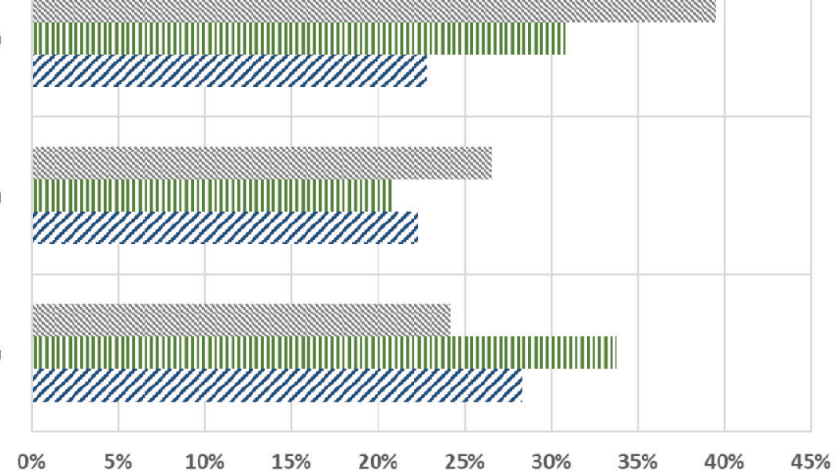

« Села ІІІ Малые города \%Областные центры и столицы республик

Рис. 6. Место рождения депутатов и администраторов в зависимости от принадлежности или непринадлежности к эндогенному ядру (2019-2020 гг.; N=960; Д=602, A=358)

В социальном взаимодействии легитимность социального актора, особенно чужака, может быть определена наличием у него легальных институционализированных символов чести и престижа, то, что Пьер Бурдьё обозначил как социальный капитал [Бурдье 1993: 74-76; 2001: 231; 2014: 305-310]. И как пишет Бурдьё, социальный капитал «производит институт клиентелы». Тот, кто обозначает, признает и делает публичным престиж, выступает высшей инстанцией. Символический капитал маркирует агента власти, ее посланника и комиссара. В этом отношении чужаки, неэндогенная элита могут быть санкционированы в качестве правомерных представителей власти. В таблице 6 представлены различные виды наград и отличий, присвоенных членам регионального элитного сообщества.

Российские государственные награды (ордена и медали) относятся к тем знакам, которые выдаются федеральной властью и связаны, как правило, с оценкой служения ей и государству. Государственные почетные звания также обозначают признание государством значимости службы. Но они часто связаны с фиксацией заслуг и квалификацией 
Таблица 6

Символический капитал и эндогенность, 2019-2020 гг., \%

\begin{tabular}{|l|c|c|c|c|c|c|c|}
\hline \multicolumn{1}{|c|}{ Элиты } & $\mathbf{1}$ & $\mathbf{2}$ & $\mathbf{3}$ & $\mathbf{4}$ & $\mathbf{5}$ & $\mathbf{6}$ & $\mathbf{7}$ \\
\hline $\begin{array}{l}\text { Неэндогенное ядро } \\
(\mathrm{N}=149)\end{array}$ & 44,4 & 7,0 & 15,5 & 3,5 & 0,7 & 0,0 & 28,9 \\
\hline $\begin{array}{l}\text { Эндогенное ядро } \\
(\mathrm{N}=69)\end{array}$ & 34,8 & 11,6 & 15,9 & 4,3 & 1,4 & 1,4 & 30,4 \\
\hline Всего (N=211) & 41,2 & 8,5 & 15,6 & 3,8 & 0,9 & 0,5 & 29,4 \\
\hline
\end{tabular}

1. Российские государственные награды (ордена, медали).

2. Почетные звания, данные российским государством.

3. Региональные почетные звания и знаки отличия.

4. Российские негосударственные награды и звания.

5. Награды Русской православной церкви.

6. Почетные ученые звания и членство в негосударственных академиях.

7. Прочее.

индивида в конкретной сфере профессиональной деятельности. Например, звание «Заслуженный деятель науки Российской Федерации» или «Заслуженный зоотехник Российской Федерации». В иерархии государственных наград первые более значимы.

Соотношение награжденных в двух рассматриваемых категориях региональной элиты соответствует их соотношению в регионах. Но они отличаются по степени наград. Мобильные персоны элиты могли функционировать в разных социальных и политических пространствах. Более того, они в этом смысле стремятся к некоторой универсальности. Они замыкаются не на регион, а на государство. Поэтому государство замечает и отмечает их в большей степени.

\section{ЗАКЛЮЧЕНИЕ}

Существует большой разброс характеристик мобильности и эндогенности властных групп по регионам. Нет единой модели. Вместе с тем показатели мобильности и эндогенности у администраторов и депутатов/политиков хотя и не совпадают, но близки.

Можно определенно утверждать, что для большинства регионов характерно усиление укорененности элиты, снижение мобильности ее членов, что выражается в увеличении (в некоторых случаях - стабилизации) показателей совпадения места рождения элитных персон, места предыдущей их работы и места их «элитного служения». Противо- 
речивые данные получены по месту первого высшего образования. Вместе с тем интегральный показатель эндогенности (эндогенное ядро) в большинстве субъектов федерации возрастает, «чужаков» становится меньше.

Наблюдается дифференциация показателей эндогенности по возрастным группам. Более молодые политики и администраторы оказываются менее мобильными, более эндогенными. Это может говорить о возникновении устойчивых региональных бассейнов рекрутирования, снижении маргинальности в элитном сообществе, стабилизации региональных властных групп, их закрытии в отношении внешних акторов.

Существуют различия в показателях эндогенности элиты в зависимости от места рождения (типа поселения).

Вопреки ожиданиям, наличие «пришлого» губернатора («варяга») не оказывает существенного влияния на динамику эндогенности региональной административной элиты, что может свидетельствовать об относительной автономности региональных бюрократов.

Одновременно наблюдается значительное отличие паттернов пространственной мобильности населения и элит в большинстве регионов. Можно предположить, что более высокая мобильность членов властных групп, чем остального населения, способствует их инновационности, большей гибкости и толерантности. Однако при снижении мобильности этой социальной группы эти качества, возможно, будут снижаться.

К общим положительным следствиям повышения эндогенности властных групп можно отнести снижение их культурной гетерогенности, сохранение и укрепление локальной культуры, что потенциально снижает культурное напряжение между элитой и населением.

\section{Литература}

Аттали Ж. На пороге нового тысячелетия. М.: Международные отношения, 1993. $136 \mathrm{c}$.

Ачкасов В.А., Абалян А.И., Полякова Н.В. «Строительство регионов»: специфика российской региональной политики идентичности // Вестник Томского гос. ун-та. 2020. № 451. С. 89-95.

Бауман 3. Индивидуализированное общество / пер. с англ. под ред. В.Л. Иноземцева. М.: Логос, 2002. LXIII, 324 с.

Бурдье П. Делегирование и политический фетишизм // Бурдье П. Начала. Choses dites / пер. с фр. Н.А. Шматко. M.: Socio-Logos, 1994. С. 231-256. 
Бурдье П. О государстве: курс лекций в Коллеж де Франс (1989-1992) / под ред. Патрика Шампаня [и др.] пер. с фр. Д. Кралечкина и И. Кушнарёвой; предисл. А. Бикбова. М.: Дело, 2016. 720 с.

Бурдье П. Практический смысл / общ. ред. пер. с фр. и послесл. Н. А. Шматко. СПб.: Алетейя; М.: Ин-т эксперимент. социологии, 2001. 562 с.

Бурдье П. Социальное пространство и генезис «классов» // Бурдье П. Социология политики: пер. с фр. М.: Socio-Logos, 1993. С. 53-97.

Бурдье П. Формы капитала // Классика новой экономической социологии: пер. с англ. и фр. / сост. В.В. Радаев, Г.Б. Юдин. М.: Изд. дом Высш. шк. экономики, 2014. С. 293-315.

Быстрова А.С., Дука А.В., Колесник Н.В., Невский А.В., Тев Д.Б. Российские региональные элиты: инновационный потенциал в контексте глобализации // Глобализация в российском обществе: сб. науч. работ / отв. ред. И.И. Елисеева. СПб.: Нестор-История, 2008. С. 99-242.

Вирт Л. Социология и локальная история // Вирт Л. Избранные работы по социологии: сб. переводов / пер. с англ. В.Г. Николаева; отв. ред. Л.В. Гирко. М.: ИНИОН РАН, 2005. С. 65-78.

Гаман-Голутвина О.В. Политические элиты России: вехи исторической эволюции. М.: РОССПЭН, 2006.

Гельман В.Я. Политические элиты и стратегии региональной идентичности // Журнал социологии и социальной антропологии. 2003. № 2. С.91-105.

Дука А.В. К вопросу о милитократии: силовики в региональных властных элитах // Властные структуры и группы доминирования: материалы Х всерос. семинара «Социологические проблемы институтов власти в условиях российской трансформации» / под ред. А.В. Дуки. СПб.: Интерсоцис, 2012. С. 94-120.

Зиммель Г. Большие города и духовная жизнь // Логос. 2002. № 34. С. 23-34.

Зиммель Г. Экскурс о чужаке // Социологическая теория: история, современность, перспективы: альманах журнала «Социологическое обозрение». СПб.: Владимир Даль, 2008. С. 7-13.

Карачурина Л., Мкртчян Н. Межрегиональная миграция в России: возрастные особенности // Демографическое обозрение. 2016. Т. 3, № 4. С. 47-65.

Королев А.А. «Новые кочевники» и российская предпринимательско-управленческая элита // Элита России в прошлом и настоящем: социально-психологические и исторические аспекты: сб. науч. статей Вып. 2 / общ. ред. А.А. Королева. М.: Изд. Национального института бизнеса, 2012. С. 10-22.

Манхейм К. Человек и общество в эпоху преобразования // Манхейм К. Диагноз нашего времени. М.: Юрист, 1994. С. 277-411.

Миллс Р. Властвующая элита / пер. с англ. Е. И. Розенталь и др.; предисл. В.Е. Мотылева. М.: Изд-во иностранной лит-ры, 1959. 543 с.

Миллс Ч.Р. Социологическое воображение. М.: Стратегия, 1998. 264 с.

Островская Е.А., Мамонтов Д.С., Спиридонов К.А., Левый И.В. Анализ межрегиональных миграционных потоков в России в проекции отдельных 
видов миграции // Журнал Новой экономической ассоциации. 2021. № 2 (50). C. $36-55$.

Парк Р.Э. Культурный конфликт и маргинальный человек // Парк Р.Э. Избранные очерки: сб. переводов / сост. и пер. с англ. В.Г. Николаев; отв. ред. Д.В. Ефременко. М.: ИНИОН РАН, 2011а. С. 236-240.

Парк Р.Э. Человеческая миграция и маргинальный человек // Парк Р.Э. Избранные очерки: сб. переводов / сост. и пер. с англ. В.Г. Николаев; отв. ред. Д.В. Ефременко. М.: ИНИОН РАН, 2011b. С. 223-235.

Рашковский Е. Маргиналы // 50/50. Опыт словаря нового мышления / под общ. ред. Ю. Афанасьева, М. Ферро. М.: Прогресс, 1989. С. 146-149.

Сорокин П.А. Система социологии. М.: Астрель, 2008. 1003 с.

Строев П.В., Кан М.И. Пространственная мобильность населения: экономический и социальный аспекты // Экономика. Налоги. Право. 2016. № 6. С. 35-41.

Тормочева В. Глобальная (им)мобильность в зеркале постмодернистских трансформаций: политический аспект // Социологическое обозрение. 2018. T. 17, № 3. С. 329-345.

Урри Дж. Мобильности / пер. с англ. А.В. Лазарева. М.: Праксис, 2012. 566 с.

Фарж А. Маргиналы // 50/50. Опыт словаря нового мышления / под общ. ред. Ю. Афанасьева, М. Ферро. М.: Прогресс, 1989. С. 143-146.

Шматко Н.А., Качанов Ю.Л. Территориальная идентичность как предмет социологического исследования // Социологические исследования. 1998. № 4. C. 94-98.

Шюти А. Чужой: очерк социальной психологии // Щютц А. Смысловая структура повседневного мира: очерки по феноменологической социологии / пер. с англ. А.Я. Алхасова, Н.Я. Мазлумяновой. М. : Ин-т Фонда «Обществ. мнение», 2003. С. 191-206.

Akhtar A.S. Dreams of a Secular Republic: Elite Alienation in Post-Zia Pakistan // Journal of Contemporary Asia. 2016. Vol. 46, № 4. P. 641-658.

Bell S. Globalisation, Neoliberalism and the Transformation of the Australian State // Australian Journal of Political Science. 1997. Vol. 32, № 3. P. 345-367.

Burnham J. The Machiavellians: Defenders of Freedom. London: Putnam \& Co., 1943. v, $202 \mathrm{p}$.

Burnham J. The managerial revolution; what is happening in the world. New York: The John Day company, 1941. 285 p.

Clark W. A. V., van Ham M., Coulter R.J. Spatial mobility and social outcomes // Journal of Housing and the Built Environment. 2014. № 4. P. 699-727.

Dahl R. Who Governs? Democracy and Power in an American City. $2^{\text {nd }}$ ed. New Haven; London: Yale University Press, 2005. xv, 355 p.

Dahrendorf R. Society and Democracy in Germany. Garden City, N.Y.: Doubleday \& Company, Inc., 1969. xvi, 457 p.

Field G.L., Higley J. Elitism. London; Boston: Routledge and Kegan Paul, 1980. $\mathrm{xi}, 135 \mathrm{p}$. 
Giddens A. Elites in the British Class Structure // Elites and Power in British Society / Ed. by P. Stanworth and A. Giddens. Cambridge: Cambridge University Press, 1974. P. 1-21.

Hasan A. The Roots of Elite Alienation // Economic and Political Weekly. 2002. Vol. 37, № 44/45. P. 4550-4553.

Higley J., Nieuwenhuysen J. Introduction // Nations of Immigrants: Australia and the USA Compared / ed. by J. Higley, J. Nieuwenhuysen with S. Neerup. Cheltenham, UK; Northampton, MA, USA: Edward Elgar Publishing, 2009. P. 1-21.

Kornhauser W. "Power Elite" or "Veto Groups" // Class, Status and Power / ed. by R. Bendix and S.M. Lipset. $2^{\text {nd }}$ ed. London: Routledge and Kegan Paul, 1961. P. 210-218.

Leinonen J. "Money Is Not Everything and That's the Bottom Line": Family Ties in Transatlantic Elite Migrations // Social Science History. 2012. Vol. 36, № 2. P. 243-268.

Meisel J.H. The Myth of the Ruling Class: Gaetano Mosca and the "Elite". With the first English translation of the final version of "The Ruling Class". Ann Arbor: University of Michigan Press, 1962. xi, 432 p.

Perkin H.J. The Third Revolution: professional elites in the modern world. London; New York: Routledge, 1996. xviii, 253 p.

Putnam R.D. The Comparative Study of Political Elites. Englewood Cliffs, N.J.: Prentice-Hall, 1976. x, 246 p.

Putnam R.D. Elite Transformation in Advanced Industrial Societies: An Empirical Assessment of the Theory of Technocracy // Comparative Political Studies. 1977. Vol. 10, № 3. P. 383-412.

Riesman D. with N. Glazer and R. Denney. The Lonely Crowd. Abridged edition with a 1969 preface. New Haven; London: Yale University Press, 1977. lxii, 315 p.

Toscano I. Geographical and social mobility in Italy: Working paper - August 2008. (University of Trento). 23 p. URL: http://www.equalsoc.org/uploaded_files/ publications/Toscano.pdf (дата обращения: 02.04.2009).

\section{Источники}

Власти Калининграда вновь видят в нацистской поэтессе «культурное наследие» // // ИA REGNUM. 14.11.2016. URL: https://regnum.ru/news/polit/2205109. html?utm_source=infox.sg (дата обращения: 16.11.2016).

Депутат Марченко об исключении из «Единой России»: с этого момента наши дороги расходятся // ИА «Фонтанка.ру». 2.11.2021. URL: https://www. fontanka.ru/2021/11/02/70231805/ (дата обращения: 03.11.2021).

«Единая Россия» исключила из партии депутата Марченко // РИА «Новости». 2.11.2021. URL: https://ria.ru/20211102/marchenko-1757421646.html (дата обращения: 03.11.2021).

Коэффициент межрегиональной (внутренней) миграции на 10000 населения // Сайт Федеральной службы государственной статистики. URL: https:// showdata.gks.ru/report/274822/ (дата обращения: 10.11.2021). 
Население по месту рождения и месту проживания на территории Российской Федерации // Итоги Всероссийской переписи населения 2010 года. URL: https://www.gks.ru/free_doc/new_site/perepis2010/croc/Documents/vol8/pub-08.03. pdf (дата обращения: 04.01.2020).

Население частных домохозяйств по продолжительности проживания, полу и возрастным группам по субъектам Российской Федерации // Итоги Bсероссийской переписи населения 2010 года. URL: https://www.gks.ru/free_doc/ new_site/perepis2010/croc/Documents/vol8/pub-08.01.pdf (04.01.2020).

Популяризация Мигель в Калининграде влияет на положительную оценку фашизма // ИA REGNUM. 16.11.2016. URL: https://regnum.ru/news/polit/2206086. html (дата обращения: 16.11.2016).

Aoraha C. Meghan Markle complained Royal Family controlled every part of her life but one in her bombshell emails. The Sun. November 16, 2021. URL: https:// www.thesun.co.uk/news/uknews/16744313/meghan-markle-royal-family-bombshellemails/ (дата обращения: 16.11.2021).

Hawken L. Meghan Markle breaks Royal rules at Trooping the Colour with offshoulder dress from Carolina Herrera. The Sun. June 9, 2018. URL: https://www. thesun.co.uk/fabulous/6488040/meghan-markle-dress-trooping-the-colour-carolinaherrera-design/ (дата обращения: 10.06.2018).

McCahill E. Meghan Markle 'faces plot from Buckingham Palace's men in grey' says royal writer. Mirror. March 3, 2019. URL: https://www.mirror.co.uk/news/uknews/meghan-markle-faces-plot-buckingham-14080423 (дата обращения: 05.03.2019).

\section{MOBILITY AND ENDOGENEITY OF REGIONAL POLITICAL AND ADMINISTRATIVE ELITES}

\section{A. Duka}

(alexander-duka@yandex.ru) Sociological Institute of the Russian Academy of Sciences - a branch of the Federal Center of Theoretical and Applied Sociology of the Russian Academy of Sciences, St.-Petersburg, Russia

Citation: Duka A. Mobil'nost' i endogennost' regional'nykh politiko-administrativnykh elit [Mobility and endogeneity of regional political and administrative elites]. Vlast' $i$ elity [Power and Elites], 2021, 8 (1): 66-99. (in Russian)

DOI: https://doi.org/10.31119/pe.2021.8.1.3 
Abstract. The article discusses the problems of social and spatial mobility of regional Russian elites (administrators and deputies). It is shown that mobility is a factor in the internal differentiation of elites. Elites are more mobile than the general population. This difference is due to the position of powerful persons in the hierarchy. At the same time, the mobility of elite persons is not constant. It changes over time.

To characterize "spatial stability" the term "endogeneity" is used, which is somewhat broader than simply fixing a certain degree of spatial mobility of an individual or social group relative to a specific biographical milestone - birth, (higher) education, occupation of a particular position, etc. in its relation to the administrative / geographical / political place. In the article, endogeneity (embeddedness) is understood as a sustainable connection of an individual (politician, administrator) with the local community, its interests and needs. "Sustainable connection" is based on embeddedness in the local community and the resulting social relations of various levels and character.

The empirical basis of the research is the biographical database of members of the elite community of ten regions. In the center of the analysis are the political and administrative elites for 2020 (1124 persons). Materials from the databases of 2010 (651 persons) and 2015 (1510 persons), as well as data from Russian Federal State Statistics Service, are also used.

It was found that there is a wide range of characteristics of mobility and endogeneity of power groups across regions. However, the indicators of mobility and endogeneity of the administrative and political elite, although they do not coincide, are close.

In most of the regions under study, there is an increase in the rootedness of the elite, a decrease in the mobility of its members. The integral index of endogeneity (endogenous core) is increasing in most of the studied subjects of the Federation.

Differentiation of endogeneity indices by age groups is observed. Younger politicians and administrators turn out to be less mobile, more endogenous. This may indicate the emergence of stable regional recruitment basins, the stabilization of regional power groups, and their closure in relation to external actors.

Contrary to expectations, the presence of an "alien" governor (appointed from Moscow) does not significantly affect the dynamics of mobility / endogeneity of the regional administrative elite, which may indicate the relative autonomy of regional bureaucrats.

Keywords: elites, deputies, administrators, region, marginality, outsiders, mobility, rootedness, endogeneity.

\section{References}

Achkasov V.A., Abalian A.I., Poliakova N.V. "Region-building": the specifics of the Russian regional identity policy, Vestnik Tomskogo gos. un-ta [Bulletin of the Tomsk State University], 2020, 451, pp. 89-95. (In Eglish). 
Akhtar A.S. Dreams of a Secular Republic: Elite Alienation in Post-Zia Pakistan, Journal of Contemporary Asia, 2016, 46 (4), pp. 641-658.

Attali J. Na poroge novogo tysyacheletiya [On the Threshold of the New Millennium]. Moscow: Mezhdunarodnyye otnosheniya, 1993. 136 p. (In Russian).

Bauman Z. Individualizirovannoye obshchestvo [The Individualized Society]. Moscow: Logos, 2002. lxiii+324 p. (In Russian).

Bell S. Globalisation, Neoliberalism and the Transformation of the Australian State, Australian Journal of Political Science, 1997, 32 (3), pp. 345-367.

Bourdieu P. Delegirovaniye i politicheskiy fetishizm [Delegation and political fetishism]. In: Bourdieu P. Nachala. Choses dites [Things say]. Moscow: Socio-Logos, 1994, pp. 231-256. (In Russian)

Bourdieu P. Formy kapitala [Forms of Capital]. In: Klassika novoy ekonomicheskoy sotsiologii: khrestomatiya [Classics of New Economic Sociology: Reader], ed. by V.V. Radayev and G.B. Yudin. Moscow: HSE, 2014, pp. 293-315. (In Russian)

Bourdieu P. O gosudarstve: kurs lektsiy v Kollezh de Frans (1989-1992) [On the State: a course of lectures at the College de France (1989-1992)]. Moscow: Delo, 2016. 720 p. (In Russian)

Bourdieu P. Prakticheskiy smysl [The Logic of Practice]. St. Petersburg: Aleteya; Moscow: Institut ekperimental'noy sotsiologii, 2001. 562 p. (In Russian)

Bourdieu P. Sotsial'noye prostranstvo i genezis «klassov» [Social space and the genesis of "classes"]. In: Bourdieu P. Sotsiologiya politiki [Sociology of politics]. Moscow: Socio-Logos, 1993, pp. 53-97. (In Russian)

Burnham J. The Machiavellians: Defenders of Freedom. London: Putnam \& Co., 1943. v+202 p.

Burnham J. The managerial revolution; what is happening in the world. New York: The John Day company, 1941. 285 p.

Bystrova A., Duka A., Kolesnik N., Nevskij A., Tev D. Rossijskie regional'nye jelity: innovacionnyj potencial $\mathrm{v}$ kontekste globalizacii [Russian regional elites: innovative potential in the context of globalization]. In: Eliseeva I.I. (ed.) Globalizacija $v$ rossijskom obshhestve: sb. nauch. trudov [Globalization in Russian society: a collection of scientific papers]. St. Petersburg: Nestor-Istorija, 2008, pp. 99-243. (In Russian).

Clark W. A. V., van Ham M., Coulter R.J. Spatial mobility and social outcomes, Journal of Housing and the Built Environment, 2014, no. 4, pp. 699-727.

Dahl R. Who Governs? Democracy and Power in an American City. $2^{\text {nd }}$ ed. New Haven; London: Yale University Press, 2005. xv+355 p.

Dahrendorf R. Society and Democracy in Germany. Garden City, N.Y.: Doubleday \& Company, Inc., 1969. xvi+457 p.

Duka A.V. K voprosu o militokratii: siloviki v regional'nyh vlastnyh jelitah [On the issue of militocracy: siloviki in regional power elites]. In: Duka A.V. (ed.) Vlastnye struktury i gruppy dominirovanija: Materialy desjatogo Vserossijskogo seminara «Sociologicheskie problemy vlasti v uslovijah rossijskoj transformacii» [Power struc- 
tures and domination groups: Materials of the tenth All-Russian seminar "Sociological problems of power institutions under conditions of Russian transformation"]. St. Petersburg: Intersocis, 2012, pp. 94-20. (In Russian).

Farge A. Marginaly [Marginals]. In: Afanas'yev Yu. And Ferro M. (eds.) 50/50. Opyt slovarya novogo myshleniya [50/50. Experience of the dictionary of new thinking]. Moscow: Progress, 1989, pp. 143-146. (In Russian).

Field G.L., Higley J. Elitism. London; Boston: Routledge and Kegan Paul, 1980. $\mathrm{xi}+135 \mathrm{p}$.

Gaman-Golutvina O.V. Politicheskie jelity Rossii. Vehi istoricheskoj jevoljucii [The political elites of Russia. Milestones of historical evolution]. Moscow: ROSSPEN, 2006. 446 p. (In Russian).

Gel'man V.Ya. Politicheskiye elity i strategii regional'noy identichnosti [Political elites and regional identity strategies], Zhurnal sotsiologii $i$ sotsial'noy antropologii [Journal of Sociology and Social Anthropology], 2003, 2, pp. 91-105. (In Russian).

Giddens A. Elites in the British Class Structure. In: Elites and Power in British Society. Ed. by P. Stanworth and A. Giddens. Cambridge: Cambridge University Press, 1974, pp. 1-21.

Hasan A. The Roots of Elite Alienation, Economic and Political Weekly, 2002, 37 (44/45), pp. 4550-4553.

Higley J., Nieuwenhuysen J. Introduction. In: Nations of Immigrants: Australia and the USA Compared. Ed. by John Higley and John Nieuwenhuysen with Stine Neerup. Cheltenham, UK; Northampton, MA, USA: Edward Elgar Publishing, 2009, pp. $1-21$.

Karachurina L., Mkrtchyan N. Mezhregional'naya migratsiya v Rossii: vozrastnyye osobennosti [Interregional migration in Russia: age characteristics], Demograficheskoye obozreniye [Demographic review], 2016, 3 (4), pp. 47-65. (In Russian).

Kornhauser W. "Power Elite” or "Veto Groups". In: Class, Status and Power. Ed. by R. Bendix and S.M. Lipset. $2^{\text {nd }}$ ed. London: Routledge and Kegan Paul, 1961, pp. 210-218.

Korolev A.A. "Novyye kochevniki» i rossiyskaya predprinimatel'sko-upravlencheskaya elita ["New nomads" and the Russian entrepreneurial and managerial elite]. In: Korolev A.A., Alekseyev S.V. (eds.) Elita Rossii v proshlom i nastoyashchem: sotsial'no-psikhologicheskiye $i$ istoricheskiye aspekty. Vyp. 2. Sbornik nauchnykh statey [Elite of Russia in the past and present: socio-psychological and historical aspects. Issue 2. Collection of scientific articles]. Moscow: Izd. Natsional'nogo instituta biznesa [National Institute of Business Publishing], 2012, pp. 10-22. (In Russian).

Leinonen J. "Money Is Not Everything and That's the Bottom Line”: Family Ties in Transatlantic Elite Migrations, Social Science History, 2012, 36 (2), pp. 243-268.

Mannheim K. Chelovek i obschestvo v epohu preobrazovaniya [Man and Society in an Age of Reconstruction]. In: Mannheim K. Diagnoz nashego vremeni [Diagnosis of Our Time]. Moscow: Yurist, 1994. S.277-411. (In Russian). 
Meisel J.H. The Myth of the Ruling Class: Gaetano Mosca and the "Elite". With the first English translation of the final version of "The Ruling Class". Ann Arbor: University of Michigan Press, 1962. xi, 432 p.

Mills Charles Wright. Sotsiologicheskoye voobrazheniye [Sociological imagination]. Социологическое воображение. Moscow: Ed. House «Strategy», 1998, 264 p. (In Russian).

Mills W. Vlastvuyushchaya elita [The Power Elite]. Moscow: Izdatel'stvo inostrannoy literatury, 1959. 543 p. (In Russian).

Ostrovskaya E.A., Mamontov D.S., Spiridonov K.A., Levyy I.V. Analiz mezhregional'nykh migratsionnykh potokov v Rossii v proyektsii otdel'nykh vidov migratsii [Analysis of interregional migration flows in Russia in the context of certain types of migration], Zhurnal Novoy ekonomicheskoy assotsiatsii [Journal of the New Economic Association], 2021, 2, pp. 36-55. (In Russian).

Park R.E. Chelovecheskaya migratsiya i marginal'nyy chelovek [Human Migration and the Marginal Man]. In: Park R.E. Izbrannyye ocherki [Selected essays]. Moscow: INION, 2011b, pp. 223-235. (In Russian).

Park R.E. Kul'turnyy konflikt i marginal'nyy chelovek [Cultural Conflict and the Marginal Man]. In: Park R.E. Izbrannyye ocherki [Selected essays]. Moscow: INION, 2011a, pp. 236-240. (In Russian).

Perkin H.J. The Third Revolution: professional elites in the modern world. London; New York: Routledge, 1996. xviii+253 p.

Putnam R.D. Elite Transformation in Advanced Industrial Societies: An Empirical Assessment of the Theory of Technocracy, Comparative Political Studies, 1977, 10 (3), pp.383-412.

Putnam R.D. The Comparative Study of Political Elites. Englewood Cliffs, N.J.: Prentice-Hall, 1976. $x+246$ p.

Rashkovskiy Ye. Marginaly [Marginals]. In: Afanas'yev Yu. And Ferro M. (eds.) 50/50. Opyt slovarya novogo myshleniya [50/50. Experience of the dictionary of new thinking]. Moscow: Progress, 1989, pp. 146-149. (In Russian)

Riesman D. with N. Glazer and R. Denney. The Lonely Crowd. Abridged edition with a 1969 preface. New Haven; London: Yale University Press, 1977. lxii+315 p.

Schütz A. Chuzhoy: Ocherk sotsial'noy psikhologii [The Stranger: Essay on social psychology]. In: Schütz A. Smyislovaya struktura povsednevnogo mira: ocherki po fenomenologicheskoy sotsiologii [The meaning structure of the everyday world: Essays on phenomenological sociology]. Moscow: Institut Fonda «Obschestvennoe mnenie» [Institute of the Public Opinion Foundation], 2003, pp. 260-310. (In Russian)

Shmatko N.A., Kachanov Yu.L. Territorial'naya identichnost' kak predmet sotsiologicheskogo issledovaniya [Territorial identity as a subject of sociological research], Sotsiologicheskiye issledovaniya [Sociological research], 1998, 4, pp. 9498.

Simmel G. Bol'shiye goroda i dukhovnaya zhizn' [The Metropolis and Mental Life], Logos, 2002, 34, pp. 23-34. (In Russian) 
Simmel G. Ekskurs o chuzhake [The Stranger]. In: Sotsiologicheskaya teoriya: Istoriya, sovremennost, perspektivyi: Almanah zhurnala "Sotsiologicheskoe obozrenie" [Sociological theory: history, modernity, prospects: almanac of the journal "Sociological Review"]. St. Petersburg.: Vladimir Dal', 2008. pp. 7-13. (In Russian)

Sorokin P.A. System of sociology. Moscow: Astrel', 2008. 1003 p.

Stroev P.V., Kan M.I. Prostranstvennaya mobil'nost' naseleniya: ekonomicheskiy i sotsial'nyy aspekty [The Spatial Mobility of Population: Economic and Social Aspects], Ekonomika. Nalogi. Pravo [Economics. Taxes. Right], 2016, 6, pp. 35-41. (In Russian)

Tormosheva Vera S. Global'naya (im)mobil'nost' v zerkale postmodernistskikh transformatsiy: politicheskiy aspekt [Global (Im)mobility in the Mirror of Postmodern Transformations: The Political Aspect], Sotsiologicheskoye obozreniye [Russian Sociological Review], 2018, 17 (3), pp. 329-345. (In Russian)

Toscano I. Geographical and social mobility in Italy: Working paper - August 2008. (University of Trento). P.13. URL: http://www.equalsoc.org/uploaded_files/ publications/Toscano.pdf (available at: 02.04.2009).

Urry J. Mobil'nosti [Mobilities]. Moscow: Praksis, 2012. 566 p. (In Russian)

Wirth L. Sotsiologiya i lokal'naya istoriya [Sociology and local history]. In: Wirth L. Izbrannyye raboty po sotsiologii [Selected works on sociology]. Moscow: INION, 2005, pp. 65-78. (In Russian) 